\title{
The Cult of Saints among Muslims and Jews in Medieval Syria
}

\author{
Josef Meri
}

Oxford: Oxford University Press, 2002. 327 pages.

Contemporary Jewish-Muslim relations are so mired in the Middle East's political conflict that most people are often quite surprised to learn of the remarkable theological, legal, and mystical intersections between both traditions. Modern political hostilities centered on the Palestinian-Israeli divide have almost entirely clouded the shared Semitic heritage of faiths that were, until just a little more than 50 years ago, invariably stamped by the Christian West with the seal of "otherness" - an "internal otherness" in the case of Judaism, and an "external otherness" in the case of Islam.

In this light, Josef Meri's work is a welcome contribution to the scholarly study of Jewish-Muslim relations. The study raises our awareness of 
both religions' common cultural and intellectual history: more specifically, to the medieval Muslim and Jewish pilgrimage culture of saint veneration in Syria, and, to a lesser extent, other regions of the Near East. The work grew out of the author's doctoral dissertation at Oxford, done under the supervision of Wilferd Madelung and Daniel Frank, and bears the mark of the many hours Meri must have spent as a scholarly archeologist digging through an enormous range of classical Arabic and Hebrew texts as well as pertinent secondary literature.

Although the concentration of the comparative analysis tilts toward the Islamic side (the author notes that the evidence for Jewish saint veneration is considerably less), he still manages to explore the parallel concepts, religious practices, and architectural facets relevant to his analysis with reasonable success. The work is not simply a descriptive account of Jewish and Muslim saint veneration, but an assessment of the psychological and cultural modes that accompany such forms of religious expression. To this end, Meri draws out some of the wider theoretical issues pertaining to the construction of sacred space and the social function of saints and pilgrimage sites.

The reader comes to learn that one reason for the flourishing of ziy Frah (pilgrimage) sites among Muslims was because they fulfilled a spiritual need for those who could not perform the hajj due to such reasons as poverty, age, or illness. Unsurprisingly, some of the ulama, among them Ibn al-Qayyim, condemned this practice, which they saw as too closely resembling the hajj, since many of the pilgrims were guilty of imitating its rites. However, none of the clerics, including the Hanbalis, disapproved of visiting the graves of pious people altogether for the purpose of acquiring blessings. The debate revolved around which practices were allowed, those sites to which one could pay homage, and the extent to which the dead profited the living.

Meri highlights some of the key arguments of both the conservative (e.g., Ibn `Aqil, Ibn Taymiyya, and Ibn al-Qayyim) and more liberal (alGhazali) camps. However, one gets the impression that he skirts the arguments of the latter group, to whom he devotes two pages and for whose views he brings only one representative, in comparison to his ten-page discussion of three Hanbali counter-views. This leaves the reader with the impression that the conservative position may have carried more theological weight. A more balanced presentation might have included the arguments of al-Razi, al-Suyuti, or even al-Nawawi, all of whom held to views on this question that were closer to al-Ghazali's. To his credit, Meri briefly 
notes the Shi ite position and the importance it attached to "lesser pilgrimages," as well as the imams' intercessory function, which most Sunni clerics would have been reluctant to accept.

Most interestingly, the reader learns that there were debates within Jewish circles about the legal status of the ziy Frah culture. In early Judaism, the legitimacy of erecting tombs over the graves of saints was contested, with the Palestinian Talmud categorically stating: "One erects no grave monuments to the dead" (p. 275). In the tenth century, the Karaite theologian Sahl b. Masliah rebuked what he considered to be the excessive practices accompanying shrine visitations:

... the [Jewish] umma was uprooted from the Homeland because they visit the graves, perfume them with incense, believe in spirits and request fulfillment of their needs from the dead and spend the night at the tomb. (p. 221)

On the whole, the conservative voices within both traditions were unable to thwart the ziy Frah culture, which was part and parcel of medieval Islamicate civilization, of which Judaism was a component. In a twist of irony, notes Meri, even Ibn Taymiyya could not resist becoming the posthumous object of the kind of saint veneration he so acerbically criticized. According to Ibn Shakir al-Kutubi's account, devotees drank the excess water and divided the remaining lotus fruits with which his body was washed.

We can be grateful to Meri for drawing our attention to some significant historical displays of interfaith solidarity at the shrines of shared revered figures, most notably at prophet Ezekiel's tomb in Iraq (also known as Hizqil and Dhu al-Kifl). Although the gravesite was within the vicinity of a synagogue, it attracted both Muslim and Jewish pilgrims from far and wide seeking Ezekiel's blessings. The shrine's Jewish and Muslim servants, who were loved by the population, ensured that a lamp was always burning so that the tomb would "glow with the light of holiness" (p. 232). Meri astutely observes that whereas the neighborhoods tended to isolate religious communities, such shrines drew them together.

My only qualm with Meri's study, one that is quite minor, concerns his vague use of the term Sufi. One is not sure what to make of his claim that among Muslims, "not all medieval saints were Sufis" (p. 66), because for the Sufis themselves the word was simply a label and had little to do with following a shaykh or belonging to a tariqah (if that is what Meri has in mind), despite the emphasis that came to be placed on allegiance to an order 
in later Islamic tradition. The goal of Sufism was sainthood (walayah), and anyone who attained it was a Sufi by default. In the classical literature, the Sufis (al-mutasawwifah) are designated by such titles as the "folk of hearts" (ahl al-qulub), the "folk of God" (ahl Allah), and the "knowers through God" ('ulama' bi-Allah). All of these designations are used, more or less synonymously, to refer to individuals characterized by a high level of spiritual realization - the same quality associated with "saints" (awliya').

In this connection, Meri also errs in representing the views of some of the early writers on sainthood. He says that according to Sarraj's Kitab alLuma', the Companions of the Prophet were not awliy $\mathbb{F}$ (pp. 66-67), which is simply not true. One of the reasons Sarraj authored the Luma' was to argue for Sufism's legitimacy, and it would have most certainly defeated his purpose to make such a claim. Meri then writes: "Later writers and mystics like al-Qushayri, al-Ghazali, and Ibn al-Arabi employ it [the term wali] specifically in the context of Sufi saints," which is also misleading if Sufi is understood in Meri's narrow sense. For all three of them, sainthood was simply the culmination of the religious life and was most perfectly exemplified by the Prophet, the earliest generations, and any Muslim who received a special kind of divine grace. As one gathers from Ibn al-'Arabi's Ruh al-Quds, walaya' could manifest itself among wandering ascetics, legal scholars, and even official court judges.

These minor shortcomings aside, Meri's scholarship is meticulous and original. It will, hopefully, be a stepping-stone for a deeper appreciation of the shared historical and religious legacy of Judaism and Islam.

Atif Khalil

Centre for the Study of Religion

University of Toronto

Toronto, Canada 